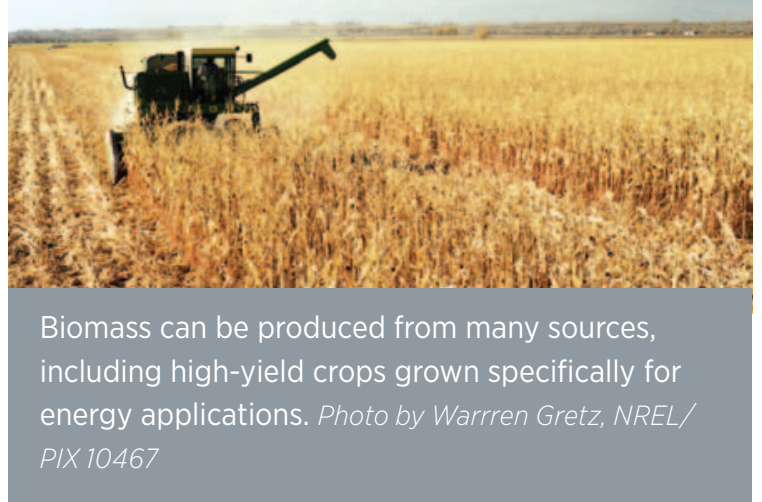

EERE also conducts R\&D on concentrating solar power (CSP) which holds potential to become cost competitive with baseload power within 15 years.

\section{Water Power}

Conventional hydropower represents approximately $7 \%$ of all U.S. electricity generation, making it the single largest renewable electricity source today. EERE pursues R\&D to improve conventional hydropower technologies while making them more environmentally friendly.

EERE also invests in innovative technologies that can generate cost-effective electricity from wave, tidal, ocean, and river currents or ocean therma energy. These marine and hydrokinetic technologies can generate renewable, environmentally responsible electricity from water sources that can be connected to the power grid. With many densely populated load centers near bodies of water, nearby markets for this predictable, renewable power source are readily available.

\section{Capturing the Wind}

Wind power generates emissions-free electricity while reducing water demand for power generation, increasing tax bases for local governments, and supporting tens of thousands of jobs - especially in construction and manufacturing. Wind energy has the potential to supply $20 \%$ of the nation's electricity by 2030 , presenting a clean, domestic, renewable energy option.
EERE works with industry, national laboratories, state and local governments, and other federal agencies to advance land-based and offshore wind turbine technologies, facilitate grid interconnection and integration, and support the responsible, widescale deployment of wind energy.

\section{Fuel Cells}

Fuel cells are a highly efficient and flexible technology for producing power and heat offering cleaner, more efficient alternatives to fossil fuel combustion. Fuel cell scalability offers significant benefits for specialty vehicles like forklifts, distributed power systems, automobiles, buses, auxiliary power units, and portable electronics.

\section{Shifting the Way Americans Move} Next Generation Vehicles

With new all-electric and plug-in hybrid vehicles rolling off assembly lines, America stands poised to begin the next chapter in its love affair with the car. These new cars will help Americans go from Point A to Point B safely, reliably, and comfortably while reducing the need for foreign oil, strengthening the nation's energy security, and protecting the environment from harmful emissions. EERE is investing in advanced battery and electric drive component manufacturing, charging infrastructure, and R\&D to drive down costs and establish the United States as a global leader in advanced vehicles.

\section{u.s. DEPARTMENT OF | Energy Efficiency \& ENERY Renewable Energy}

EERE Information Center 1-877-EERE-INFO (1-877-337-3463) eere.energy.gov/informationcenter

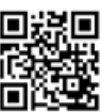

DOE/GO-102011-3269 • August 2011 eere.energy.gov

\section{u.s. DePARTMENT OF | Energy Efficiency \&} Renewable Energy

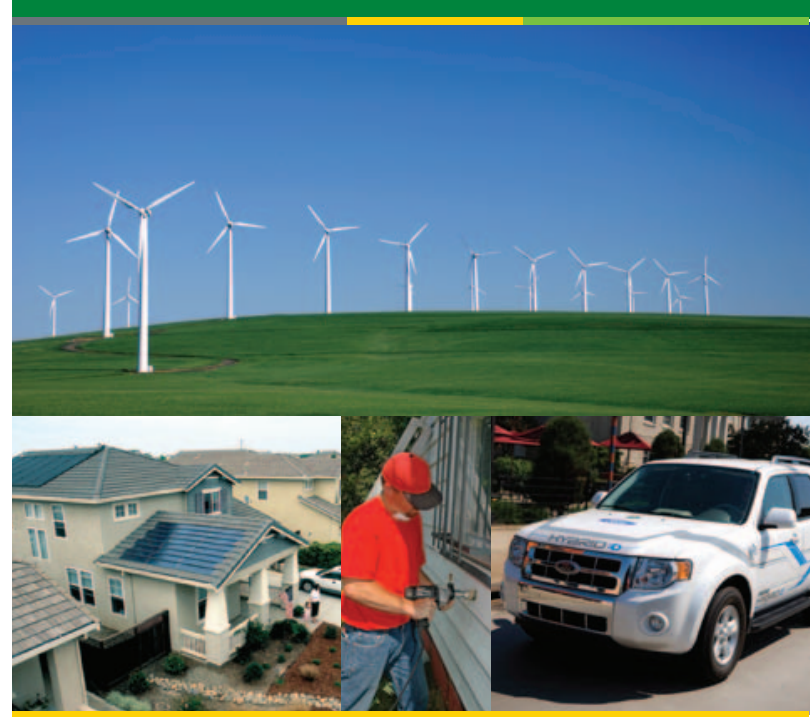

\section{Securing America's Clean Energy Future}

The Office of Energy Efficiency and Renewable Energy (EERE) invests in clean energy technologies that strengthen the economy, reduce dependence on foreign oil, and protect the environment. EERE leverages partnerships with the private sector, state and local governments, DOE national laboratories, and universities to transform the nation's economic engine to one powered by clean energy. 
EERE supports research and development (R\&D) that spurs innovation, helping create the next generation of vehicles, drive down the cost of renewable energy, and formulate advanced biofuels. EERE also supports robust domestic manufacturing. For instance, although the United States developed much of today's advanced battery technology, America ceded its manufacturing lead. Therefore, EERE made historic investments in advanced batteries and electric-drive components that will help make America the world's leader in advanced battery manufacturing. If it's invented in America, it can be made in America.

\section{A More Efficient America Making our Buildings Better}

Saving energy saves money. EERE pursues R\&D on building technologies that not only saves energy and achieves significant cost savings, but also improves comfort for American families and businesses

Through R\&D, energy codes, public awareness, and energy alliances with the private sector, EERE is creating better buildings across the nation. EERE

\section{EERE Programs 2011 Budget}

(in \$ millions)

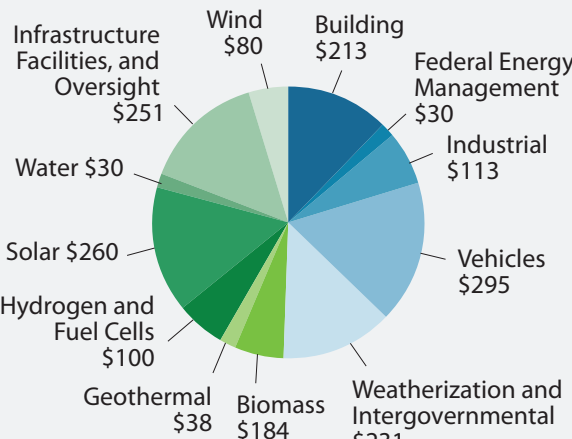

$\$ 38 \quad \$ 184 \quad \$ 231$ Inernmental

EERE operates with a budget of $\$ 1.8$ billion accelerates the adoption of energy upgrades in existing buildings while developing cutting edge technologies and practices to build new, highly efficient buildings.

\section{Government Leading by Example}

As the nation's single largest energy consumer, the federal government possesses the greatest opportunity to lead by example, make its facilities and vehicle fleets more efficient, and save taxpayers' money. EERE helps implement sound, cost-effective energy management and investments to enhance the nation's energy security and environmental stewardship. EERE assists federal agencies to meet laws and regulations that enhance energy efficiency, deploy renewable energy, improve water efficiency, and reduce carbon emissions.

\section{Strengthening Industry}

The industrial manufacturing sector maintains America's largest energy appetite. So, EERE collaborates closely with industry, establishing innovative solutions to reduce manufacturing energy intensity to save businesses money and make them more competitive in the global market. Driving down industry energy costs keeps jobs in the United States while reducing reliance on foreign oil and other imports.

\section{Supporting Local Clean Energy Projects}

EERE provides funding and technical assistance to state and local governments, community action agencies, utilities, Indian tribes, and U.S. territories to assist them with their renewable energy and energy efficiency programs. EERE develops information products, tools, and market transformation activities that remove barriers to building the clean energy economy in communities throughout the United States.

EERE also works with states to make home energy upgrades in low-income households. These upgrades make homes safer, healthier, more comfortable, and more affordable through energy savings.

\section{Deploying Renewable Energy at Speed and Scale}

\section{Growing a Clean Energy Future}

Organic plant material, or biomass, is an abundant, renewable resource for biofuels, bioproducts, and biopower. Biomass energy can be produced from wood, agricultural residues, algae, waste streams, or even high-yield crops grown specifically for energy.

EERE accelerates biomass-based fuel and product adoption, helping America reduce its fossil fuel use. Maintaining a balanced research portfolio of biomass feedstocks, conversion technologies, and fuel types, EERE strives to make cellulosic ethanol costcompetitive by 2012 while facilitating infrastructure development to increase biofuel use.

\section{Harnessing the Earth's Heat}

Geothermal energy offers a clean, reliable, renewable resource that can either provide direct heat or generate baseload electricity. EERE conducts R\&D and demonstration projects that seek to tap this massive resource, providing a cost-effective electric power generation option.

\section{Shooting for the Sun}

In 1962, President Kennedy challenged the U.S. to win the global space race by sending a man to the moon within a decade. America responded to this "moonshot," investing in education and R\&D that spurred entire new industries. Eight years later, Neil Armstrong bounded on the moon's surface.

Today, EERE is taking a SunShot: a goal to make utility-scale solar systems cost competitive - without subsidy - within a decade. EERE is collaborating with DOE's Office of Science and Advanced Research Projects Agency-Energy (ARPA-E) along with industry on SunShot to achieve a $75 \%$ cost reduction. EERE works to improve the reliability and lower the costs of solar modules, the balance of systems, and power electronics, reducing barriers to solar power in the marketplace. 